\title{
INDIGENOUS KNOWLEDGE ON MEDICINAL PLANTS USED BY THE PEOPLE OF KRISTI VILLAGE, POKHARA, NEPAL
}

\author{
Harilal Upadhaya \\ Department of Botany, Prithvi Narayan Campus, Tribhuvan University, Nepal
}

\begin{abstract}
The medicinal knowledge of plants is very common among the tribal people but much of the information is not yet documented. The purpose of the present study was to document information on medicinal plants used by the people of Kristi village, Pokhara, Nepal. A total of 42 medicinal plant species belonging to 39 genera and 29 families were documented each with local name, uses and mode of administration. The study indicated that the indigenous people widely accepted the traditional knowledge on the utilization of medicinally important plants.
\end{abstract}

Key words: Families, genera, indigenous people, Kristi, medicinal plants

\section{INTRODUCTION}

The plants and plant products have been used as medicine worldwide. Traditional medicine practices and ethnobotanical information play a vital role in scientific research. However, these traditional medicine practices are in the danger of being lost due to urbanization and habitat destruction as the knowledge about plants generally get passed from one generation to another verbally.

Nepal is a small country but rich in biological diversity. The study on medicinal plants in Nepal started only after the first floristic exploration made by Francis Buchanan- Hamilton in 18021803 whose collection was noted by David Don in "Prodromus Florae Nepalensis" (Don,1825). There are over 10669 species of flora in Nepal ranging from fungi to angiosperms (Chaudhary, 1998). The history of the utilization of plant resources in Nepal was first made by Banerji documenting various edible and medicinal plants of eastern Nepal (Banerji, 1955). Later elaborated by various authors such as Dobremez (1976), Manandhar (1994), Siwakoti and Verma (1996), Siwakoti and Siwakoti (1998), Parajuli (2000), Shrestha et al. (2000), Joshi and Joshi
(2001), Acharya and Pokhrel (2006), Dangol (2008), Malla and Chetri (2009), Joshi and Joshi (2011).Although several previous studies have been conducted on the use of local plants for traditional healing practice at different parts of Nepal by Manandhar (1994), Siwakoti and Siwakoti (1998), Parajuli (2000), Acharya and Pokhrel (2006), Dangol(2008), Malla and Chetri (2009) and Joshi and Joshi (2011) the indigenous knowledge on the use of medicinal plants of several rural areas has not yet been documented. The present study aimed to investigate and document the ethnomedicinal knowledge of Kristi village, a rural area within Pokhara metropolitan, Kaski district, Nepal.

\section{MATERIALS AND METHODS}

\section{Study Area}

The study was conducted at Kristi village, one of the rural areas of Pokhara Metropolitan, Kaski district, Nepal. It lies at the southern part of Pokhara. The village is surrounded by Nirmal Pokhari in the east, Pumdi-Bhumdi in the west, Syangja district in the south while the northern part is a part of Pokhara metropolitan. The elevation of the site ranges from 700 to 1465 
$\mathrm{m}$ a.s.1. The study area covers an area of 17.98 $\mathrm{km}^{2}$ with rich vegetation. The climate is humid sub-tropical marked by the seasonal variation in rainfall and temperature.

\section{Data collection}

The present study was conducted from January 2017 to June 2018 covering different villages within Kristi (the then different wards within the then Kristi village development committee) at the interval of every month. The primary data on ethnomedicinal information was gathered through direct field observation, oral interviews and discussions with traditional healers and elders during the field visits. After noting all the necessary information on a plant species that is used traditionally for medicinal purpose, a sample was collected for an herbarium preparation following the method of Lawrence (1974). The plant specimens were identified based on the identification and nomenclature key of previous authors such as Hara et al., (1978, 1979, 1982); Malla et al., (2009); Shrestha et al., (2000). The final verification of the specimens was confirmed by comparing with the Herbarium specimens at the department of Botany, Prithvi Narayan Campus, Pokhara.

\section{RESULTS AND DISCUSSION}

A total of 42 species of medicinal plants belonging to 39 genera and 29 families were collected. Botanical names are enumerated alphabetically followed by family name, local name, uses and mode of administration in Table 1. In terms of number, Moraceae appeared as the largest family with four species followed by Asteraceae with three species; Amaranthaceae, Lauraceae, Anacardiaceae, Euphorbiaceae, Rutaceae, Lamiaceae, Zingiberaceae, Poaceae with two species each and the remaining 19 families were represented by a single species. Different parts of the plants like rhizomes, roots, leaves, barks, fruits are being used to cure different diseases by the local inhabitants. Altogether 19 species were used for their roots and rhizomes followed by 14 species for leaves, 10 species each for bark and fruits/seeds for the treatment of different ailments which is shown in figure 1. Nine plant species are used for treating skin diseases, seven species each for diarrhea and dysentery, 6 species for fever and 5 species for cuts and wounds which is expressed in figure 2. Out of a total of 42 plant species, 37 species are administered for more than one disease while four species are being used for the treatment of one ailment only.

The current finding reveals that although elder people are familiar with the traditional use of local plants for medicinal purpose, the younger people of the study area do not know the names of the plants and their medicinal values. A few elder people still follow the medicinal practices and traditional knowledge for their livelihood. Due to recent advances in medicinal system, most of the people are attracted towards it and the indigenous knowledge of medicine is in decline and eroding. Likewise, many plant species are on the verge of extinction due to destructive harvesting practices. Considering the above facts, steps should be taken for the documentation of medicinally important plants and also their mass scale cultivation and conservation by the respective stakeholders. 
Table 1: list of medicinal plants used by the people of Kristi Village, Kaski, Nepal

\begin{tabular}{|c|c|c|c|c|}
\hline Botanical Name & Family & Local Name & Uses & Mode of administration \\
\hline $\begin{array}{l}\text { Achyranthes bidentata } \\
\text { Blume }\end{array}$ & Amaranthaceae & Dattiwan & $\begin{array}{l}\text { i) Common Cold } \\
\text { ii) Stomatitis }\end{array}$ & $\begin{array}{l}\text { i) Root paste is given } \\
\text { ii) The root powder is } \\
\text { given }\end{array}$ \\
\hline Adhatoda vasica $\mathrm{L}$. & Acanthaceae & Asuro & $\begin{array}{l}\text { i) Catarrh } \\
\text { ii) Skin disease }\end{array}$ & $\begin{array}{l}\text { i) Leaf paste applied on } \\
\text { the nose } \\
\text { ii) Root paste massaged } \\
\text { and washed }\end{array}$ \\
\hline Allium sativum L. & Amaryllidaceae & Lasun & $\begin{array}{l}\text { i) Fever, Cough } \\
\text { ii) Blood pressure }\end{array}$ & $\begin{array}{l}\text { i) taking leaves and bulb } \\
\text { juice } \\
\text { ii) Chewing raw bulb }\end{array}$ \\
\hline Amaranthus spinosus L. & Amaranthaceae & Ludo & $\begin{array}{l}\text { i) Menorrhagia } \\
\text { ii) Eczema }\end{array}$ & $\begin{array}{l}\text { i) Plant decoction } \\
\text { drunken } \\
\text { ii) Applied crushed } \\
\text { leaves and roots }\end{array}$ \\
\hline $\begin{array}{l}\text { Artemisia dubia Wallich } \\
\text { ex Besser }\end{array}$ & Asteraceae & Tite pati & $\begin{array}{l}\text { i) Cuts, wounds } \\
\text { ii) Nervous disease }\end{array}$ & $\begin{array}{l}\text { i) Leaf paste applied } \\
\text { ii) Taking an infusion of } \\
\text { leaves }\end{array}$ \\
\hline $\begin{array}{l}\text { Artocarpus } \\
\text { heterophyllus Lam. }\end{array}$ & Moraceae & Rukh kathar & $\begin{array}{l}\text { i) Skin disease } \\
\text { ii) Diarrhoea/ } \\
\text { Dysentery }\end{array}$ & $\begin{array}{l}\text { i) Leaf paste applied } \\
\text { ii) Taking a decoction of } \\
\text { roots }\end{array}$ \\
\hline $\begin{array}{l}\text { Artocarpus lakoocha } \\
\text { Roxb. }\end{array}$ & Moraceae & Badahar & i) Purgative & i) Seeds administered \\
\hline Berberis aristata Dc. & Berberidaceae & Chutro & $\begin{array}{l}\text { i) Anthelminthic } \\
\text { ii) Jaundice }\end{array}$ & $\begin{array}{l}\text { i) Taking root decoction } \\
\text { ii) Bark and root paste } \\
\text { taken }\end{array}$ \\
\hline Bidens pilosa $\mathrm{L}$. & Asteraceae & Kalo kuro & i) Cuts and wounds & i) Plant juice applied \\
\hline Bombax ceiba $\mathrm{L}$. & Bombacaceae & Simal & $\begin{array}{l}\text { i) Burns } \\
\text { ii) Paralysis }\end{array}$ & $\begin{array}{l}\text { i) Root paste applied } \\
\text { ii) Bark decoction } \\
\text { applied as a hot compress }\end{array}$ \\
\hline $\begin{array}{l}\text { Castanopsis indica } \\
\text { Roxb.ex Lind. }\end{array}$ & Fagaceae & $\begin{array}{l}\text { Dhale } \\
\text { kartush }\end{array}$ & i) Chest pain & i) Bark paste applied \\
\hline Centella asiatica $\mathrm{L}$. & Apiaceae & Ghod tapre & $\begin{array}{l}\text { i) Cuts and wounds } \\
\text { ii) Fever } \\
\text { iii) Memory }\end{array}$ & $\begin{array}{l}\text { i) Leaf paste applied } \\
\text { ii) Leaf paste given } \\
\text { iii) Leaves chewed }\end{array}$ \\
\hline $\begin{array}{l}\text { Cinnamomum tamala } \\
\text { (Buch. -Ham.) Ness \& } \\
\text { Eberm. }\end{array}$ & Lauraceae & Tejpat & $\begin{array}{l}\text { i) Fever } \\
\text { ii) Bad odour of } \\
\text { mouth }\end{array}$ & $\begin{array}{l}\text { i) Bark given } \\
\text { ii) Bark chewed }\end{array}$ \\
\hline $\begin{array}{l}\text { Citrus aurantifolia } \\
\text { (Christ.) Swingle }\end{array}$ & Rutaceae & Kagati & $\begin{array}{l}\text { i) Dysentery and } \\
\text { Diarrhoea }\end{array}$ & $\begin{array}{l}\text { i) Administration of fruit } \\
\text { and juice }\end{array}$ \\
\hline Citrus aurantium L. & Rutaceae & Suntala & i) Skin ointment & $\begin{array}{l}\text { i) Fruit and bark paste } \\
\text { applied }\end{array}$ \\
\hline
\end{tabular}




\begin{tabular}{|c|c|c|c|c|}
\hline $\begin{array}{l}\text { Colebrookea } \\
\text { oppositifolia Sm. }\end{array}$ & Lamiaceae & Dhurseli & $\begin{array}{l}\text { i) Epilepsy } \\
\text { ii) Wounds }\end{array}$ & $\begin{array}{l}\text { i) Root juice given } \\
\text { ii) Leaf juice used }\end{array}$ \\
\hline $\begin{array}{l}\text { Cucurbita maxima } \\
\text { Duchesne }\end{array}$ & Cucurbitaceae & Pharsi & $\begin{array}{l}\text { i) Cooling internal } \\
\text { inflammation }\end{array}$ & i) Fruits eaten \\
\hline $\begin{array}{l}\text { Curcuma domestica } \\
\text { Valeton }\end{array}$ & Zingiberaceae & Besar & $\begin{array}{l}\text { i) Fever } \\
\text { ii) Skin disease }\end{array}$ & $\begin{array}{l}\text { i) Rhizome taken } \\
\text { ii) Rhizome paste applied }\end{array}$ \\
\hline Cynodon dactylon $\mathrm{L}$. & Poaceae & Duboo & $\begin{array}{l}\text { i) Epistaxis } \\
\text { ii) Paralysis }\end{array}$ & $\begin{array}{l}\text { i) Plant juice applied } \\
\text { ii)Fruit applies as hot } \\
\text { compress }\end{array}$ \\
\hline
\end{tabular}

Dioscorea bulbifera L. Dioscoreaceae Ban tarul

I) Diarrhoea and i) Consuming tubers after Dysentery boiling

Eupatorium
adenophorum Spreng

Asteraceae Banmara

i) Cuts and wounds

a) Juice of plant

Euphorbia pulcherrima

Euphorbiaceae

ii) Fever

ii) Juice of root

Willd.ex Klotzsch

Ficus benghalensis L.

Moraceae

Lalupate

i) Boils

i) Latex of plant applied

ii) Skin disease

ii) paste of the leaf

i) Diarrhoea and

i) Decoction of bark Dysentery

ii) Milky latex applied

ii) Pains and bruises

Ficus religiosa L. Moraceae Peepal

i) Skin disease i) latex applied

ii) Stomach pain

ii) chewing of bark

Jatropha curcas L

Euphorbiaceae

Sajiwan
i) Swollen gums
ii) Lactogogue

i) Twigs used

ii) Leaf decoction used

Lablab purpureus L.

Fabaceae

Hiude simi

i) skin disease

i) Leaf juice applied

Litsea monopetala

Lauraceae

Kutmero

i) Astringent and

i) Bark juice administered

(Roxb.) Pers diarrhoea

ii) Pains

ii) Barks and roots powder

Mangifera indica L. Anacardiaceae Amp

i) Rheumatism applied externally

ii) Scabies and

i) Bark decoction used skin disease

Melia azedarach L. Meliaceae

Bakaino

i) Laxative

ii) Headache

ii) Latex used

Melia azedarach L. Meliaceae Bakaino

i) Oil from seed administered

Menthe arvensis L. Lamiaceae Pudina

i) Antispasmodic

ii) Bark paste applied

Menthe arvensis L. Lamiaceae Pudina

ii) Vomiting

i) Dried plant taken

Musa paradisiacal L. Musaceae

Kera

i) Diarrhoea and

ii) Leaf juice given dysentery

i) Unripe fruit taken

ii) Diabetes

Oxalis corniculata L. Oxalidaceae

Chariamilo
i) Dysentery
i) Aerial
parts
ii) Eye cataract
administered
iii) Redness of eye
ii) Infusion of leaf used
iii) Plant juice applied

Psidium guajava L. Myrtaceae Amba

i) Dysentery

i) Bark juice administered 


\begin{tabular}{|c|c|c|c|c|}
\hline Rhus javanica Miller & Anacardiaceae & Bhakimlo & $\begin{array}{l}\text { i) Colic } \\
\text { ii) Stomachic }\end{array}$ & $\begin{array}{l}\text { i) Grounded fruit taken } \\
\text { ii) Fruits chewed }\end{array}$ \\
\hline Rubus ellipticus Sm. & Rosaceae & Aiselu & $\begin{array}{l}\text { i) Gastritis } \\
\text { ii) Fever }\end{array}$ & $\begin{array}{l}\text { i) Roots juice taken } \\
\text { ii) Roots chewed }\end{array}$ \\
\hline $\begin{array}{l}\text { Saccharum officinarum } \\
\text { L. }\end{array}$ & Poaceae & Ukhu & i) Jaundice & i) Stem juice taken \\
\hline Solanum melongena L. & Solanaceae & Bhanta & $\begin{array}{l}\text { i) Heart problem } \\
\text { ii) Cough and cold }\end{array}$ & $\begin{array}{l}\text { i) A decoction of root } \\
\text { used } \\
\text { ii) Green fruit roasted } \\
\text { and eaten }\end{array}$ \\
\hline $\begin{array}{l}\text { Terminalia chebula } \\
\text { Retz. }\end{array}$ & Combretaceae & Harro & $\begin{array}{l}\text { i) Cuts and burns } \\
\text { i) Asthma }\end{array}$ & $\begin{array}{l}\text { i) Fruit paste applied } \\
\text { ii) Fruit powder taken }\end{array}$ \\
\hline $\begin{array}{l}\text { Tinospora cordifolia } \\
\text { (Willd.) Miers }\end{array}$ & Menispermaceae & Gurjo & $\begin{array}{l}\text { i) Diuretic } \\
\text { ii) Aphrodisiac }\end{array}$ & $\begin{array}{l}\text { i) Fresh juice taken } \\
\text { ii) Infusion of powdered } \\
\text { stem taken }\end{array}$ \\
\hline Urtica dioica $\mathrm{L}$. & Urticaceae & Sishnu & $\begin{array}{l}\text { i) Malaria } \\
\text { ii) Diabetes }\end{array}$ & $\begin{array}{l}\text { i) A decoction of root } \\
\text { taken } \\
\text { ii) Cooked leaves taken }\end{array}$ \\
\hline Zingiber officinale Rosc. & Zingiberaceae & Aduwa & $\begin{array}{l}\text { i) Sinusitis } \\
\text { ii) Dyspepsia }\end{array}$ & $\begin{array}{l}\text { i) Rhizome juice put } \\
\text { inside the nose } \\
\text { ii) Dried rhizome powder } \\
\text { eaten with rock salt }\end{array}$ \\
\hline Ziziphus zuzuba Mill. & Rhamnaceae & Bayer & $\begin{array}{l}\text { i) Blood purifier } \\
\text { ii) Vomiting }\end{array}$ & $\begin{array}{l}\text { i) Fruits eaten } \\
\text { ii) Root paste taken }\end{array}$ \\
\hline
\end{tabular}

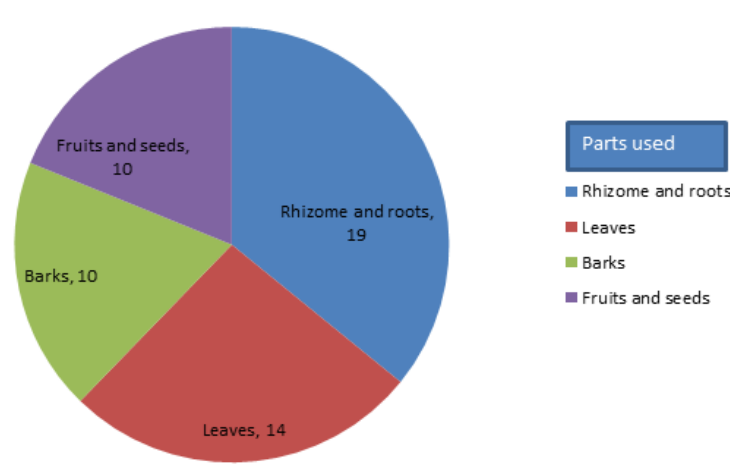

Fig. 1: Number of plant species with parts used for the treatment of different ailments

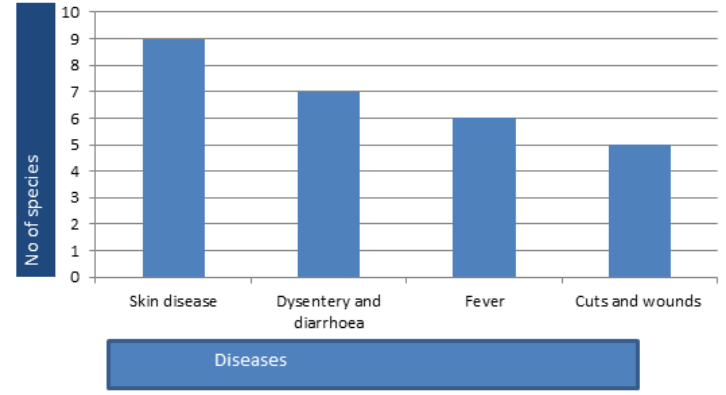

Fig. 2: Number of Plant species for the treatment of common diseases

\section{ACKNOWLEDGEMENTS}

I am very thankful to all those villagers who assisted me during field data collection. I also extend my sincere gratitude to Narayandatta Bastakoti, Department of Botany, PNC, for 
his constant and consistent support during the study period. A very special thanks go to Prof. Dr Chandra Bahadur Thapa for his valuable suggestions and encouragements.

\section{REFERENCES}

Acharya (Siwakoti), E. and B. Pokhrel (2006). Ethnomedicinal plants used by Bantar of Bhaudaha, Morang, Nepal. Our nature, 4: 96-103.

Banerji, M.L. (1955). Some edible and medicinal plants from East Nepal. Journal of the Bombay Natural History Society, 53; 153-155

Dangol, D.R. (2008). Traditional uses of plants of common land habitats in Western Chitwan, Nepal. J.Inst.Agri.Anim.Sci. 29: 71-78.

Chaudhary, R.P. (1998). Biodiversity in Nepal: status and conservation. S.Devi, Saharanpur, India, Tecpress Books, Bangkok, Thailand

Don, D. (1825). Prodromus Florae Nepalensis. London

Dobremez, J.F. (1976). Exploitation and Prospects of Medicinal plants in Eastern Nepal. Mountain Environment and Development, SATA, Kathmandu, 97-110.

Hara, H. and L.H.J. Williams (1979). An enumeration of the Flowering plants of Nepal. Vol. 2, British Museum of Natural History, London.

Hara, H., A.O.Charter and L.H.J. Williams (1982). An enumeration of the Flowering plants of Nepal. Vol.3. British Museum of Natural History, London.

Hara, H., W.T. Stearn and L.H.J. Williams (1978). An enumeration of the Flowering plants of Nepal. Vol.1. British Museum of Natural History, London.

Joshi, K.K. and S.D. Joshi (2001). Genetic Heritage of Medicinal and Aromatic Plants of Nepal Himalayas, Kathmandu: Buddha
Academic Publishers and Distributers Pvt. Ltd.

Joshi, K. R. Joshi and A.R. Joshi (2011). Indigenous Knowledge and Uses of Medicinal Plants in Macchegaun, Nepal. Indian Journal of Traditional Knowledge. 10(2): 281-286.

Lawrence, G.H.M. (1974). Taxonomy of Vascular Plants, Oxford and IBM, Pub. Co., New Delhi.

Malla, B. and R.B. Chetri(2009). Indigenous Knowledge of Ethnomedicinal plants of Kavrepalanchowk district, Nepal. Jour.Sci. Engg. and Tech. 5: 96-109.

Manandhar, N.P. (1994). An Ethnobotanical survey of herbal drugs of Kaski district, Nepal. Fitoterapia. 65(1): 7-13.

Parajuli, S.P. (2000). Ethnobotanical study at Khadbari Municipality of Sankhuwasabha district, Nepal. Banko Janakari. 10(20): 2934.

Siwakoti, M. and S.Siwakoti (1998). Ethnomedicinal uses of Plants Among the Limbu of Morang district, Nepal. Ecoprint. 5(1): 79-84.

Siwakoti, M. and S.K. Verma (1996). Medicinal plants of the Eastern, Nepal. J.Econ. Taxon.Bot. Additional series, 12, Scientific Publishers, Jodhpur, India, 423-438.

Shrestha, K.K., N.N. Tiwari and S.K. Ghimire (2000). Medicinal and Aromatic plants, Database of Nepal. In: Proceedings of NepalJapan joint Symposium on Conservation and Utilization of Himalayan Medicinal Plant Resources, 2000, Kathmandu, Nepal pp.53-74.

Received 7 July 2018

Revised accepted 21 August 2018 